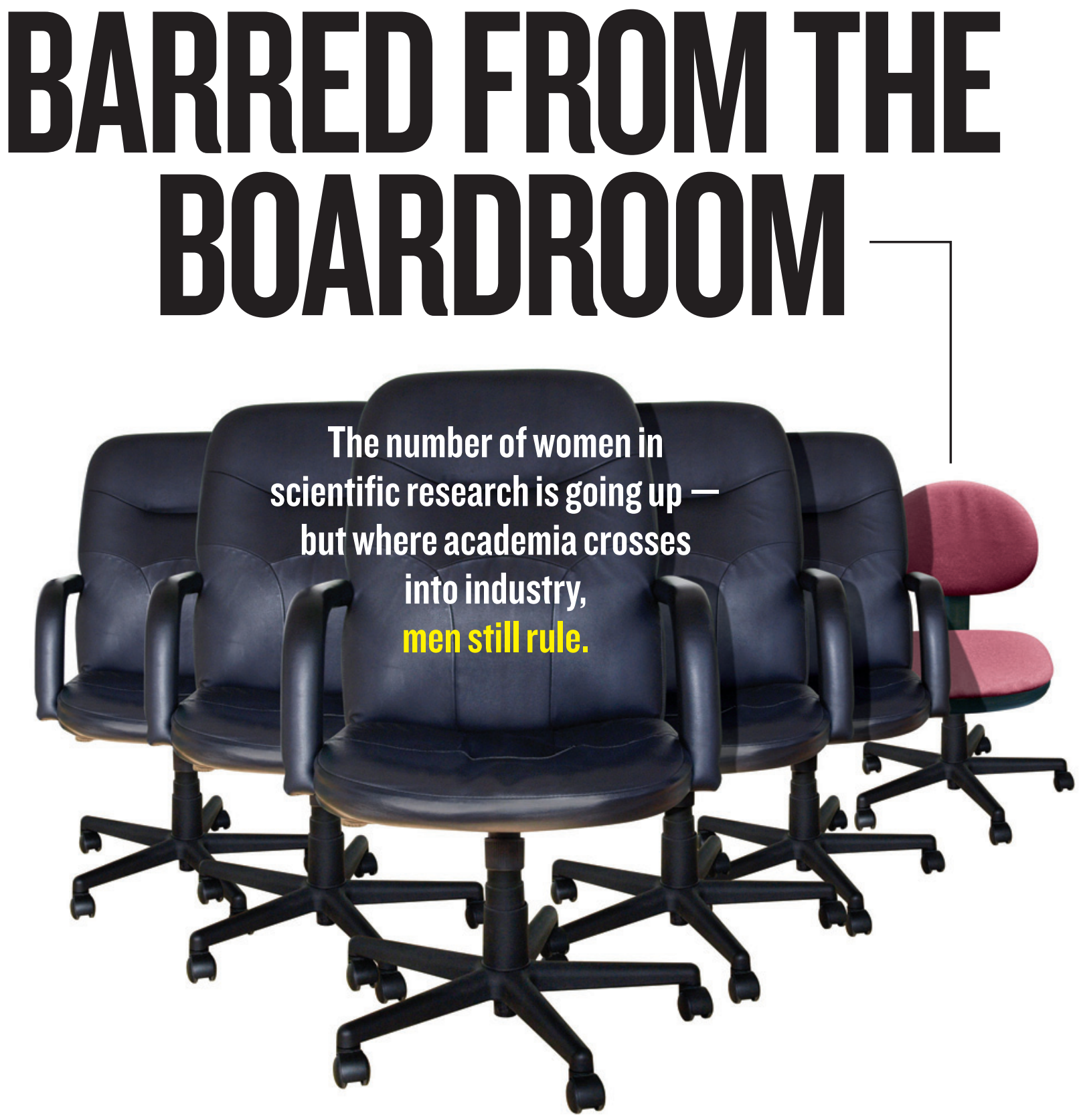

BY ALISON MCCOOK

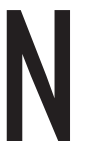
ancy Hopkins started Googling her colleagues in spring 2012. She mentally scanned the hallways of her institution at the Massachusetts Institute of Technology (MIT) in Cambridge - along with the campuses of other elite institutions - for the offices of men she knew who had founded companies. Then she clicked on the websites of their firms, and counted the number of men and women serving on their scientific advisory boards (SABs), a prestigious position for researchers who steer the company's scientific direction.

It was an informal exercise, rather than a systematic survey. But Hopkins, a molecular biologist at MIT and a long-time campaigner for women in science, found the results shocking. A sample of 12 of the companies she examined had a 
total of 129 SAB members; only 6 were women. "I was completely stunned," says Hopkins. "And it made me sad. I thought, 'gee, why don't these men want to work with [MIT] women?' We have such incredible women faculty."

The proportion of women in industrial and academic science has shot up over the past 20 years. According to the US National Science Foundation, women make up $25 \%$ of tenured academics in science and engineering and more than $25 \%$ of industry scientists in research and development. But when it comes to academics engaging in commercial work - patenting their discoveries, starting biotech companies or serving on SABs - the picture is less progressive. Studies have confirmed Hopkins' impression that even leading female scientists are often absent from these roles. "The secret club [of men] used to be going to the lab and conferences," says Fiona Murray, who studies life-sciences entrepreneurship at MIT. "That world has changed a lot, but we have a new venue where it is still difficult for women to play a similar role."

Experts in industry and academia speculate that the disparity could reflect the small numbers of women in certain specialized fields; the demands of family life; or a residual male clubbiness. Whatever the reasons, this stubborn gender gap hurts everyone, says Bonnie Bassler, a molecular biologist at Princeton University in New Jersey. "I think the companies would do better science by having the best people on their board. And I think these women, who are great scientists, would do better science in their labs by having access to these ideas."

"Everybody's losing," says Bassler.

\section{HIDDEN PROBLEM}

For much of the 1980s and 1990s, there were more than 11 men for every one woman in the science faculty at MIT. Things started to change 20 years ago, when Hopkins, as the first chair of MIT's Committee on Women Faculty in the School of Science, and her team drove through major increases in the hiring of women. By 2006 , one out of every five biology faculty members on the MIT campus was a woman.

At a dinner last April to honour these achievements and mark her retirement from the lab, Hopkins spoke about the work still to be done. She talked about a list she had been given by a graduate of Harvard Business School in Boston, Massachusetts, showing the names of scientists in the area who had received funding from a local venture-capitalist firm. Among 100 names, only one was a woman. The list would not have surprised Hopkins more than 30 years ago, when she had been told by a colleague that "women aren't allowed" to found biotech companies. But to see such a dearth of academic women in modern biotechnology was upsetting.

Around that time, Hopkins embarked on her Google search. She was particularly interested in SABs because they consist mainly of working scientists who are often invited by the company's academic founders - a social process that could reveal conscious or unconscious biases against female academics. And membership in advisory boards comes with advantages: it can tip members off to promising tools and areas of research, and lead to other lucrative prospects, such as consulting. Plus, for a few meetings per year, board members are paid a sometimes-substantial fee, given stock options, or both.
The first name Hopkins looked up was Eric Lander, founding director of the Broad Institute of MIT and Harvard. She typed "Eric Lander companies" into the search engine. Scrolling through the results, she came upon Verastem, a cancer stem-cell company founded in 2010 by Lander and others, including Robert Weinberg, a cancer researcher at the Whitehead Institute in Cambridge. She counted 14 people on Verastem's SAB; all were men.

Entering "Phil Sharp companies" brought up Alnylam Pharmaceuticals, a Cambridge-based firm co-founded by the Nobel prizewinning molecular biologist at MIT in 2002. The company, which is developing therapies based on RNA interference, had one woman on its 11-person SAB. "Bob Langer companies" yielded a handful of the 20-plus firms that the MIT bioengineer has helped to launch, including Taris Biomedical in Lexington, Massachusetts, which focuses on genitourinary conditions, and the biopharmaceutical company Blend Therapeutics in Watertown, Massachusetts. Neither SAB included any women. (Weinberg and Lander say that they were not involved in selecting the SABs at Verastem, and Langer that he was not involved with the process at Blend or Taris. Sharp says that at Alnylam, choosing the $\mathrm{SAB}$ required "agreement between" the founders, chief executive, venture capitalists and other people already brought into the company.)

Hopkins included in her search a few scientists from other institutions, such as Harvard University in Cambridge and Memorial Sloan-Kettering Cancer Center in New York. Overall, among the full-time professors affiliated with a sample of 14 companies she reviewed, only $5 \%$ of founders or SAB members were women. Although boards change over time, that fraction was much the same as of last month.

Last July, Hopkins began circulating her results to a handful of faculty members at MIT and to scientists further afield. Vicki Sato, a professor of biology and management at Harvard with a long career in the biotechnology industry, says she could not believe what she was seeing. "I was stunned by the sampling she had done, and told her she had to be wrong," says Sato. "But I knew deep down she was right."

\section{GLOBAL CONCERN}

More rigorous studies have reached similar conclusions. In a paper published last October ${ }^{1}$, Murray, Toby Stuart at the University of California, Berkeley, and Waverly Ding at the University of Maryland in College Park reviewed all publicly available lists of US biotech SABs, starting in the 1970s and including about 500 companies. Although women represented between $12 \%$ and $30 \%$ of academically active $\mathrm{PhD}$ holders over that time period, the percentage of women on SABs never exceeded $10.2 \%$ (see 'Inequality on board'). Even when the researchers compared male and female faculty members with similar levels of achievement, measured by factors such as publication and citation counts, male scientists were roughly twice as likely to join SABs as female ones.

SABs are not the only commercial forum in which academic women seem to be disadvantaged. US women also receive patents about $40 \%$ as often as men ${ }^{2}$, start businesses half as often ${ }^{1}$ and receive significantly less funding for the start-ups that they do launch ${ }^{3}$. This is not just a US problem: a study released in April 2012 by the Royal Society of Edinburgh found that women 
are underrepresented on the boards of UK science, technology, engineering and mathematics companies ${ }^{4}$. That is despite the fact that including women seems to be beneficial: a 2012 report from Credit Suisse in Zurich, Switzerland, found that worldwide, companies with women on the board have higher share prices than those with all-male boards ${ }^{5}$.

\section{INVITATION ONLY}

So what is going on? For SABs, Hopkins thinks that the answer is simple: women are not asked. When she noticed the stark patterns in board memberships, Hopkins asked some of her female colleagues - including one she believed was an "absolute star" - if they had ever been invited to serve on boards. All of them said no. "In the end, these stories are very sad," says Hopkins. "People know they're excluded, and it's costly professionally. They're embarrassed to talk about it. It's like not being asked to dance."

But the picture is not so simple, says Paul Schimmel, a former colleague of Hopkins who is now based at the Scripps Research Institute in La Jolla, California, and is a co-founder of Alnylam. He says that he has tried to ensure equal gender participation in his lab and his companies for the past 20 years. "There's no lack of effort, I tell you," says Schimmel. But serving on a board "can be a lot of work" conference calls, e-mails, travel several times a year and thick documents to review - and women often bear the majority of domestic work and child care. At least one woman has turned down Schimmel's invitation to serve on an SAB because of family responsibilities, he says. Indeed, research has shown that female academics with children are less likely than those without to patent their discoveries ${ }^{6}$.

Some prominent female scientists disagree. Carolyn Bertozzi, a chemical biologist at the University of California, Berkeley, who has two young children and one on the way, says that she is always willing to make time to serve on the research advisory board at GlaxoSmithKline, which entails attending two-day meetings twice a year for "generous" compensation. The meetings teach her about what it takes to make a drug, including medicinal chemistry, regulatory issues and intellectual property; that helps with her start-up, Redwood Bioscience in Emeryville, California, which has two female SAB members out of four. Bertozzi acknowledges that her situation is unusual: her female partner is a stayat-home mother. But Bassler, too, says that the work involved in $\mathrm{SABs}$ is worth the sacrifices. "If I were asked to serve on a board, I wouldn't do something else," she says. Bassler has been invited to serve on two SABs in her career, but "of course" would accept another invitation if it arose.

Research seems to support the idea that it is a lack of invitations - not a lack of time - that reduces female membership in biotech SABs. Murray, Stuart and Ding found that both men and women tend to join SABs on average around the 20th year after completing their $\mathrm{PhDs}^{1}$ - often a time when the major strain of child rearing is over. This suggests that family obligations are not holding back women more than men. And in interviews at a leading institution that Murray declined to name, women consistently reported they had rarely been invited to serve on their colleagues' SABs - which was not the case in a matched sample of men ${ }^{7}$.

Stuart says that the disparity is most likely to be a result of social connections and unconscious bias among men. "If you're male, you're slightly more comfortable shooting the shit with your male colleagues, and they're who come first to mind when you're putting these boards together. You may assume - 'oh, she's got two kids, she's not going to be interested' - and then not invite her."
But companies say that they can have difficulty finding women with the right experience, because there are fewer women than men in academia overall. At Alnylam, says Schimmel, the type of science and the diseases it hopes to treat "considerably narrow the size of the pool of highly qualified senior investigators, regardless of gender". (A statement from the company notes that women represent "nearly 30\%" of Alnylam's management team.) At Taris, says Langer, the SAB had to include mostly clinical experts in urology, who are generally men. And Verastem found that there were few prominent female biologists who focus on cancer stem cells, says chief medical officer Joanna Horobin. At least one woman declined the offer to join the SAB, Horobin says, because she was already working with a competing company.

The academics and biotech companies interviewed for this story say that they hope the situation will change. At Alnylam, people have "discussed openly the issue of gender and the SAB", says Schimmel. "All of us support strongly the idea of addressing the 'gender problem' in a thoughtful way and are actively working on it." In Lander's opinion, more important than the make-up of the SAB is the selection of the company's board of directors - who "control the entire company". Two out of seven directors at Verastem are women.

Women can also make the first move, says Helen Blau, a stem-cell biologist at Stanford University in California, who has served on the advisory boards for several start-ups. She broke into commercialization by patenting discoveries and talking to companies at conferences about her work. The effort paid off: companies have licensed at least a dozen of her patents, which helped Blau to get consulting jobs, board invitations and now her own start-up, Didimi in Berkeley, California.

Hopkins, meanwhile, has not let the issue lie. After she discussed her data with MIT colleagues, the group decided to forward the findings to the university's provost, Chris Kaiser. It turned out that Lydia Snover, director of institutional research at MIT, had already started mining faculty CVs across the entire institution for information about activities such as patenting, technology licensing and participation in SABs. If MIT finds gender differences and can help to do something about them, it will, says Snover. "We want all [faculty members] to be involved in the same way."

Hopkins wants to see all institutions follow MIT's example. In academia, people used to believe that "time would fix things naturally", and that women would eventually move up the ranks, she says - and this attitude may still exist when it comes to academics moving into industry. "I think [the gender disparity in SABs] is what universities would look like if we hadn't stopped, analysed what was going on, and changed it. If you don't put attention to it, it doesn't happen."

Alison McCook is a freelance writer and editor in Philadelphia, Pennsylvania.

1. Ding, W., Murray, F. \& Stuart, T. Acad. Mgmt J. http://dx.doi.org/10.5465/ amj.2011.0020 (2012).

2. Ding, W. W., Murray, F. \& Stuart, T. E. Science 313, 665-667 (2006).

3. Robb, A. M. \& Coleman, S. Sources of Financing for New Technology Firms: A Comparison by Gender (Ewing Marion Kauffman Foundation, 2009); available at go.nature.com/hdfa6q

4. Tapping All Our Talents: Women in Science, Technology, Engineering and Mathematics: A Strategy for Scotland (Royal Society of Edinburgh, 2012); available at go.nature.com/b8xrkb.

5. Credit Suisse Research Institute Gender Diversity and Corporate

Performance (Credit Suisse, 2012); available at go.nature.com/vw2rsa.

6. Whittington, K. B. Work Occup. 38, 417-456 (2011).

7. Murray, F. \& Graham, L. Ind. Corp. Change 16, 657-689 (2007). 